\begin{tabular}{|c|c|c|}
\hline \multirow{2}{*}{$\begin{array}{l}\text { BENTHAM OPEN } \\
\text { CrossMark }\end{array}$} & $\begin{array}{c}\text { The Open Conference Proceedings } \\
\text { Journal }\end{array}$ & $\begin{array}{l}\text { The Openen } \\
\text { Conferen }\end{array}$ \\
\hline & $\begin{array}{l}\text { Content list available at: www.benthamopen.com/TOPROCJ/ } \\
\text { DOI: } 10.2174 / 2210289201607020039\end{array}$ & \\
\hline
\end{tabular}

\title{
The Role of Fungi and Lichens in the Biodeterioration of Stone Monuments
}

\author{
Ornella Salvadori ${ }^{1, *}$ and Annalaura C. Municchia ${ }^{2}$ \\ ${ }^{1}$ Laboratorio Scientifico, Soprintendenza Speciale per il Patrimonio Storico Artistico ed Etnoantropologico e per il \\ Polo Museale Della Città di Venezia e dei Comuni Della Gronda Lagunare, Venice, Italy; \\ ${ }^{2}$ Dipartimento di Scienze, Università Roma Tre, Rome, Italy
}

\begin{abstract}
This review elucidates current knowledge on the significant role of fungi and lichens in the biodeterioration of stone monuments. The effect caused by many epilithic lichen species in the deterioration of different types of stone has been extensively investigated and demonstrated. Nonetheless, many aspects of the deterioration mechanisms of microcolonial fungi (MFC) and endolithic lichens are still to be proved. An interesting hypothesis has recently been put forward involving the secretion of siderophores like compounds. Lichens can provide bioprotection for stone surfaces, acting as a barrier against weathering, retaining moisture, increasing waterproofing, reducing thermal stress and erosion, and absorbing pollutants. Nevertheless, the evaluation of biodeterioration $v s$. bioprotection cannot be generalised, since it can vary according to the behaviour of different species, as well as being affected by both the lithotype and the environment. In addition to the laboratory studies, more field studies of biological communities are required, to analyse their establishment and succession in natural conditions and after conservation treatments. In order to guarantee the best decision for stone conservation, cleaning operations should not be based on a generalised approach, but should rather be based on a careful evaluation of different aspects concerning biodeterioration and bioprotection.
\end{abstract}

Keywords: Biodeterioration, Bioprotection, Color, Fungi, Lichens, Stone.

\section{INTRODUCTION}

Research on the biodeterioration of stonework has increased considerably over the second half of the last century $[1,2]$. From a biological point of view, stone represents an extreme habitat with large variations in environmental factors such as temperature, water availability, UV radiations and nutrients. Moreover, vertical or subvertical surfaces are even more difficult to be colonized due to higher desiccation conditions [3].

The role of photoautotrophs and chemioautotrophs, pioneer colonizers, has been investigated in depth in recent decades, and the importance of heterotrophs in stone deterioration has been confirmed $[2,3]$. The role of fungi in geomicrobiology and in the deterioration of monuments has for many years been neglected or underestimated, as they were considered secondary colonizers compared to other microorganisms (chemiolithotrophic bacteria, cyanobacteria, algae) or lichens. The importance of fungi in the decay of rocks was asserted strongly by Krumbein [4] who, at the beginning of the 1990s, observed black fungi on marble monuments and realized their role in stone deterioration $[5,6]$.

On the other hand, the role of lichens in biodeterioration of stone works have been recognised by many authors [7 - 11] and their effectiveness in the deterioration of rocks and neogenesis of minerals was the object of recent papers and review [12 - 16].

Microorganisms can establish different relationships with the substrate: epiliths, growing on the stone surface, and endoliths, living in the interior of the stone. Endoliths are subdivided according to, their ecological niche in

\footnotetext{
* Address correspondence to this author at the Laboratorio Scientifico, Soprintendenza speciale per il Patrimonio storico artistico ed etnoantropologico e per il Polo museale della città di Venezia e dei comuni della Gronda lagunare, Cannaregio 3553, 30121 Venice, Italy; Tel/Fax: +39041720661; Email: ornella.salvadori@beniculturali.it
} 
chasmoendoliths colonizing preexisting fissures and cavities, cryptoendoliths, colonizing structural cavities within porous rocks, and euendoliths, actively dissolving and penetrating into the stone [17]. Some species are known to be strictly endolithic (e.g. endolithic lichens), while other microorganisms can live on and/or within the rock. The chemical and structural characteristics of lithotypes, surface roughness, porosity and their state of conservation, as well as environmental conditions and climate are the key factors influencing the establishment and growth of microorganisms $[3,18]$. A high stone bioreceptivity together with favourable environmental conditions can induce a rapid biological colonization in just a few years [19,20], and cleaning and restoration treatments can positively or adversely affect the subsequent recolonization $[21,22]$.

Stone biodeterioration is ascribed to two different mechanisms: biogeophysical or mechanical processes and biogeochemical processes. They are not mutually exclusive but are assumed to act cooperatively; moreover biodeterioration is one of those factors that can contribute to stone decay together with other chemical and physical weathering.

\section{FUNGI}

Two main groups of fungi, ecologically and taxonomically separate, were isolated from stone monuments: (i) Hyphomycetes and Coelomycetes and (ii) black meristematic or MCF, and black yeasts [23 - 26].

The species belonging to the first group are common both in the soil and in the air, they generally develop in moderate and humid climate where organic substances are available. Hyphomycetes include species with colourless or brightly coloured colonies (hyaline Hyphomycetes) and species producing dark brown, green-black, or black colonies (dematiaceous Hyphomycetes). Hyphomycetes excrete organic acids and can actively dissolve carbonates, they produce different kinds of pigments, but only a few species are melanine producers [23, 27]. They generally require high levels of humidity and organic substances to develop. In spite of their presence in biofilms on outdoors stone monuments [27 - 30], they are frequently responsible for the deterioration of wall paintings, caves and restored stone artifacts [3, $31-33]$.

The MCF belongs to Ascomycetes, principally to the orders Chaetothyriales, Dothideales, and Capnodiales $[24,34,35]$, and were isolated mostly, but not exclusively in arid and semi-arid environments. Previously black fungi were known mainly as plant, animal and human parasites and were only occasionally isolated from air or soil. The isolation of MCF and black yeasts by conventional culture techniques were notoriously very hard [36], but isolation protocols are now available [37]; moreover, identification of the isolates is often impossible on the basis of culture and microscopic morphology which requires application of molecular diagnostics [38]. Although cultural features and the microscopic morphology of species are highly characteristic, taxa are genetically extremely diverse, suggesting a considerable phylogenetic distances between different species [39].

The deterioration of stone and minerals induced by fungi is generally ascribed to biogeophysical and biogeochemical processes that are not mutually exclusive but are assumed to act together, and the latter are believed to be more important. The filamentous structures of fungal hyphae favour their penetration into the substrate, depending on its structure, chemical composition and state of conservation. Fissures, cracks, cavities, pores and grain boundaries represent advantage for penetration and provide a more favourable microhabitat compared to the stone surfaces. Fungi can also perforate intact minerals [40]. Penetration can be also favoured by turgor pressure inside hyphae and melanin. Moreover, EPS produced by fungi facilitate fungal biofilm formation and the attachment to the rock, and increase mechanical pressure giving rise to shrinking and swelling [39].

Biogeochemical processes involve the production of metabolites which react with stone to form secondary minerals. Fungi excrete a large number of organic acids (oxalic, citric, acetic, formic, gluconic, glyoxylic, fumaric, malic, succinic, and pyruvic), which can act as chelators [23, 27, 41]. In addition, the role of carbonic acid derived from the respiratory carbon dioxide production, should be taken into account. Precipitation of secondary minerals (carbonates and oxalates) on and within rock had been formed during fungal colonization and mineral dissolution, forming a crust on the rock surface and mineral precipitation around hyphae that can progressively cement fissures and cracks [42]. Moreover fungi produce siderophores, low molecular weight structures generally classified into two structural groups hydoxamates and catecholate compounds, which have a high specificity for chelating or binding iron [23, 27, 39]. Their role in the etching of microfractures on olivine and other silicate has been shown in laboratory experiments [43].

The major part of studies dealing with stone monuments alterations have concerned the Mediterranean basin, which is characterized by dry and hot climate or temperate climate [6, 44, 45], and to a lesser extent tropical climates [29, 46]. 
Sterflinger [23] and Burford [45] reported some lists of common fungal species isolated from building stone and rocks (sandstone, marble, granite, limestone, soapstone, quartzite, andesite, and basalt) in various geographical and climatic zones. Hyphomycetes prevail in moderate and humid climate but can also be found in tropical climate, they usually produce organic acids and pigments of different color, whereas the species from arid and semiarid climate usually do not produce acids and always display a brown-black pigmentation due to melanin [23, 46]. A number of recent investigations focused on fungi growing on limestone in tropical climates; after 6 and 9 months of outdoor exposure of limestone coupons inoculated with microorganisms from black biofilm 977 isolates were obtained, and $90 \%$ of the species detected belonged to the Ascomycota [47]. One hundred and seventeen isolates of melanized fungi were subsequently recovered, by classical and molecular methods, from limestone surfaces located in the Mediterranean island of Mallorca; many of them do not correspond to any sequence deposited in public databases, suggesting they could be of unknown genera [37].

Many authors believe that black meristematic fungi, or microcolonial fungi (MCF), are the most important in the deterioration of stone $[6,48]$. Despite their heterotrophy, these fungi can grow on exposed stone being oligotrophic, with only a limited supply of carbon, which might be contained in dust, waste microbial products, or pollutants [49 - 51]. It is well known that stone surfaces are exposed to high levels of solar radiation, high temperature, and to prolonged periods of desiccation alternating with rainy and damp periods. MCF contain melanin as cell wall pigment, which protect them against environmental agents (e.g. UV radiation, Xand y-rays) and cellular lysis. Moreover, mycosporines and carotenoids ( $\beta$-carotene, s-carotene, phytoene, torulene and torularhodin) may protect fungi against excessive UV radiation, act as antioxidants, osmoprotectors and provide desiccation tolerance [25, 35, 52].

Microcolonial fungi together with cyanobacteria, algae and lichens, are poikilohydric microorganisms and can have active metabolic or dormancy periods according to water availability. As they are resistant to multiple and variable stress factors, and have a wide range of tolerance, they are considered poikilo-tolerant. Usually, in oligotrophic conditions they form small black clump-like colonies on stone, consisting of isodiametrically dividing cells, from which hyphae can branch (Fig. 1). Where there is an abundant supply of carbon and optimal environmental conditions, meristematic fungi can grow profusely on and into the stone, causing a large dark colouration. Widespread fungal colonization has been found in a Venetian cemetery, forming a grey patina that fully covered the limestone surfaces of the partially buried tombstones surrounded by a thick vegetation [53] (Fig. 2). In a similar environment, the inner garden of the archaeological museum of the city of Messina, a statue sculpted in Carrara marble was covered by a black patina caused to fungal growth [54, 55]. The grey colour of 'Noto' calcarenite in Southern Sicily (Italy) is also due to predominantly fungi [56]. It is likely that this kind of patina is more common on stone monuments than suggested in the literature. It is important to note that, where analyses have not been performed, grey-black patinas are often misinterpreted and ascribed to the presence of photosynthetic microorganisms (cyanobacteria and/or algae) which can form patinas of a similar appearance or to accumulation of airborne particulate matter. MCF can also form orange patinas or spots on granite and sandstone, due to the presence of carotenoids [23].

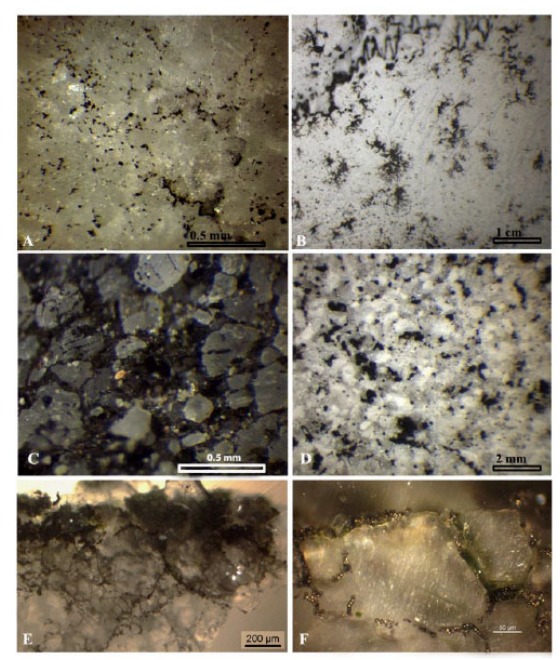

Fig. (1). Marble (A, C) and limestone (B, D) surfaces colonized by black meristematic or microcolonial fungi (MCF). Marble cross sections (E, F) showing the penetration into the substrate along intercrystalline spaces. 
According to a conceptual model for rock microcolonial fungi proposed by Chertov and Gorbushina [57] the availability of organic nutrients is the dominant factor limiting their development on stone surfaces in European temperate and Mediterranean climates, even under favourable climatic conditions, while the growth becomes very intensive in the presence of water. It is therefore recommended that organic matter be removed from monuments in order to prevent fungal growth.

Black fungi can also form associations with algae not resulting in a well-defined thallus structure, the so-called "borderline lichens" and they often co-occur on the same stone surface with lichens [58]. It is well known that fungi can form dark rock varnishes in desert environments, due to the oxidation of manganese and iron, but similar alterations have not been recorded on stone monuments $[1,23,59]$.

As demonstrated in both laboratory and field experiments, in the absence of an external carbon source, the establishment of fungi on stone is essentially dependent upon the characteristics of the substrate. Marble slabs exposed outdoors were colonized after 6-8 years, once superficial roughness had increased [60, 61], whereas porous stone and mortars were colonized after just a few months of exposure [23]. Hoppert et al. [62] studied colonization on samples taken from a linear transect in an Austrian glacial recession area with a known age of exposure. They found that black fungi were the first colonizers, having appeared 1-2 years after the rock was exposed in the atmosphere, followed by green algae, cyanobacteria and endolithic lichens.


Fig. (2). (A) Tombstones in the Old Jewish Cemetery (Venice, Italy). Grey discoloration of limestone (Istrian stone) due to colonization by black meristematic fungi. (B) Cross section stained by PAS. (C) Resin casts showing the fungal distribution pattern (bar $=0.1 \mathrm{~mm}$ ). (D) Detail of endolithic hyphae (bar $=20 \mu \mathrm{m})$. (E) Micrograph of fresh slide of the black meristematic fungus colonizing the stone.

Synthetic materials used for the treatment of stone during conservation practices can favor the growth of fungi, representing an increase in nutrient sources [3]. The application of biocide in combination with these compounds can, however, reduce the risk of fungal colonization [22, 63]. Black meristematic fungi frequently colonize fillings made up with inorganic materials (powdered marble, calcium carbonate, sand, quartzite) and acrylic resin, achieving a surface development and penetration to a depth of $1 \mathrm{~cm}$, depending on grains size [64]. 



Fig. (3). Biopits formed by black colonies of Lichenothelia sp. on limestone (A), SEM photograph at higher magnification (bar = $0.1 \mathrm{~mm})$ (B).

MCF growth is not limited to the stone surface, on marbles black fungi penetrate into the intercrystalline spaces contributing to the loosening and detachment of crystals and leading to the formation of pitting (or biopitting) [45, 48]. The pigmentation of fungal cells decreases with greater depth and the hyphae appear colourless, underling the light protective function of black pigments [6, 53, 62]. Sterflinger and Krumbein [48] considered dematiaceous fungi as being one of the principle agents responsible for biopitting on Mediterranean marble and limestone (Fig. 3). They described four different types of pitting and isolated fungal strains from all of them. The inoculation of marble samples with fungi has shown that they are able to penetrate the substrate actively and produce pits. Camara et al. [65], studying fungal colonization on three dolostones from monuments and natural outcrops, confirmed that the intercrystalline penetration was the initial stage of stone fungi interactions, followed by intracrystalline penetration and finally the complete disaggregation of the crystals. The different stages of interactions with the dolostones depend on the extent and type of porosity. These observations were confirmed in a study on the deterioration of four Romanesque churches in Segovia (Spain) [66]. It is, according to other authors, difficult in many cases to establish whether the pits are of biological origin or whether they represent a site with favorable conditions for the growth of microorganisms [67]. Lombardozzi et al. [68] created an interactive on-line biopitting database using the literature on this topic and found that cyanobacteria are the group most associated with pitting.

So far the mechanism of deterioration achieved by microcolonial fungi is not completely understood. It is well known they do not produce organic acids [36, 69, 70], unlike Hyphomycetes, and for this reason some authors supported the physical penetration of MCF due to mechanical forces and suggested an important role of cell rigidity, melanin, turgor pressure and directional growth [71, 72].

Favero-Longo et al. [73] investigated in the laboratory the interactions of some MCF (Coniosporium perforans, $C$. uncinatum and Sarcinomyces petricola) and endolithic lichens with carbonate (travertine, limestone, marble) and silicate (granite, gneiss, sandstone) rocks. The penetration patterns of tested strains were different in the different lithotypes and reached a depth alike those reported for lichens, from some hundreds of microns to several millimeters. The release of iron-chelating molecules (siderophores-like compounds) were observed in cultures and the dissolution of an iron-poor limestone upon incubation with desferrioxamine, a hydroxamate siderophore, confirmed the ability to mobilize calcium under iron limitation. These results suggest that siderophore-like compounds likely represent the repeatedly invoked chemical agents responsible for biodeterioration of both silicate and carbonate rocks, such as pitting and etching.

According to Cutler and Viles [26] patinas produced by fungi might have a protective effect on stone surfaces.

\section{LICHENS}

The deterioration ability of lichens is essentially due to the mycobiont which is in strict contact with the substrate. Generally lichen species present on monuments do not vary from the species present on the surrounding rocks and, given that the possibility to take samples from stone monuments is often very limited, many studies on lichen-stone interactions were performed on samples coming from natural rocks.

Biodeterioration is generally attributed to a combination of physical mechanisms (e.g. pressure exerted by 
expansion and contraction of the thalli, adhesion of rhizines and hyphal penetration) and chemical factors, due to the interaction of carbon dioxide, organic acids and lichen substances with complex properties. The action of epilithic species on different lithotypes, e.g. carbonatic rocks, sandstone, granite, serpentinite, volcanic tuff, schist, gneiss, limestone, obsidian, and dolomite, was largely investigated [66, 74 - 84]. Endolithic lichens were generally less studied notwithstanding their large spreading on monuments, although papers dealing with topic increased in the last decades.

Thalli of epilithic lichens develop on the stone surface but their hyphae generally penetrate the substrate in much or less extent. The capacity of lichens to alter the substrate is related both to physiological differences among species and to the physico-chemical characteristics, texture and structure of the substrate. Thallus penetration in the stone is especially related to its texture and mineralogical-petrographic features. Epilithic crustose lichens can firmly adhere to the substrate forming a well defined border line with either no or negligible penetration, they can penetrate along preexisting fractures and cleavage planes of minerals or show a major hyphal penetration within the rock matrix. In lichen thalli from siliceous or intermediate rocks, clasts of different minerals (calcite, quartz, feldspar, micas, etc.) detached from the substrate were frequently observed, they often showed sign of corrosion and etching on their faces. In thalli from limestone, minerals deriving from the substrate were less frequently observed. Some clasts can derive from wind or rain transportation and are included in the thalli by passive uptake mechanisms, as well as inorganic microspherules of different composition.

The neoformation of minerals by lichens, due to the interactions of oxalic acid and other compounds with chelating ability, is well known and depends both on the species and the chemical composition of the substrate. Calcium oxalates, in the two hydration forms whewellite and weddellite, are the most common biomineralogical products and are formed and deposited extracellularly between hyphae. The occurrence of calcium oxalate is generally higher on calcareous rocks and rocks containing calcium bearing minerals, nevertheless it can be present also in lichens growing on substrate where calcium is almost absent. Calcium oxalates can deposit in different parts of epilithic lichens, depending on the species: only on the thallus surface, on the surface and inside the thallus, in the whole thallus and even within the stone down to the depth reached by fungal hyphae penetrating it [74, 79] (Fig. 4). Magnesium, copper, ferric or manganese oxalates can be formed depending on the mineralogical composition of the substrate. Iron oxides and hydroxydes were identified as reddish layer on lavas, basalt, granite, and sandstone [13]. Lichens can decompose minerals such as biotite, quartz and feldspars and form siliceous relicts and amorpous silica, as well as poorly ordered alumino-silicates.

Among the most deteriorating lichens we can remember Dirina massiliensis $f$. sorediata, a particularly aggressive species responsible for the biodeterioration of stonework and frescoes (Fig. 5). It is coastal lichen occurring both on limestone and siliceous rocks, generally in rather shaded situations on steeply inclined surfaces [85, 86]. On calcareous substrata a lot of calcium oxalate, deriving from the calcium chelation by oxalic acid, accrues in the thalli together with substrate materials, namely calcite, gypsum and pigments (if present in the substrate), and causes a thickening of the thalli (Fig. 6). The high content of inorganic oxalate in the white thalli gives them a "gypsum appearance" and some authors referred to them as lichen encrustations whereas others do not recognize the lichen nature of these "encrustations".

Hyphae penetrate into the calcite substrate to a depth of $20 \mathrm{~mm}$ and calcium oxalate is also deposited within the stone. The deteriorative action of this lichen can also concern other kind of substrate, such as stucco, brick, mortar, acidic stone and the glass/lead interface of glass windows [85]. Seaward [86] reported a dramatic spread in Europe and, more particularly, in England of this species as consequences of environmental changes, and particularly of atmospheric pollution which caused a rapid disappearance of other pollution-sensitive species. The vegetative reproduction allowed a fast colonization of large areas of artworks' surfaces in few years, also in areas not exposed to rainfall as $D$. massiliensis does not need to be directly wet by rainwater.

In spite of their large presence on stone monuments, endolithic lichens have been much less studied in depth than epilithic ones and even today, due to their inconspicuous growth, they are overlooked and not always recognized by people involved in stone conservation [87 - 90]. The development of biomass inside the stone and the depth of penetration vary a lot among different species. A thorough study on the anatomy of five calcicolous endolithic lichens showed that the photobiont layer reaches about the same depth in the substrate, generally to $100-180 \mu \mathrm{m}$, but the distribution pattern and the depth of penetration of hyphae within the stone vary considerably among species [88]. Verrucaria baldensis has the thickest and deepest thallus reaching $2.7 \mathrm{~mm}$ from the surface. According to other authors, hyphae of endolithic lichens can occasionally reach a depth of $19 \mathrm{~mm}$. After the death and the detachment of fruiting bodies pitting formation appears on the stone surface; pits diameter ranges from 0.2 to 1-2 mm, depending on the size of ascocarps of different species (Fig. 7A). These empty pits, also called biopits, that are progressively enlarged by water 
action (rainfall, water run off, water accumulation) forming pits of major dimensions. These biopits can coalesce and form larger interconnected depressions (called (biotroughs) successively enlarged and the stone surfaces previously colonized by endolithic lichen appear deteriorated more rapidly than uncolonized surfaces. The microscale biopitting induced by endolithic lichens could give rise to mesoscale features as solution basin development on limestone [91]; however at the end of these processes no evident traces of the processes responsible of its formation (with or without biological mediation) are recognizable.
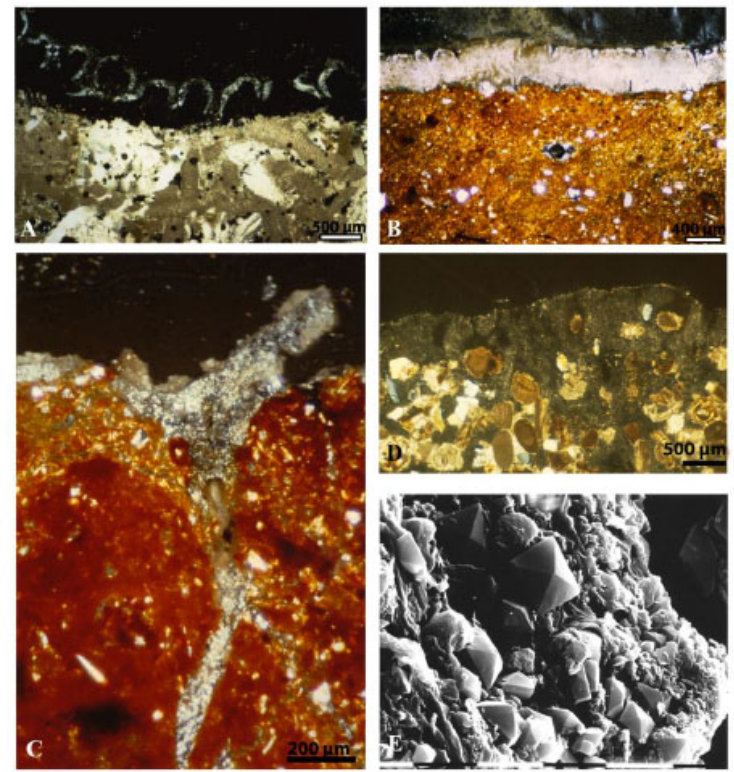

Fig. (4). Thin sections of (A) Caloplaca flavescens on Vicenza stone, (B) Diploschistes euganeus on shingle, (C) Lecidea fuscoatra on shingle, (D) Dirina massiliensis on biocalcarenite. Calcium oxalates are deposited only on the surface (A); in the whole thallus (B); in the thallus and in the substrate, along the hyphal bundles (C). (E) SEM photograph of calcium oxalate (weddellite) deposited outside fungal hyphae $(\mathrm{bar}=10 \mu \mathrm{m})$.

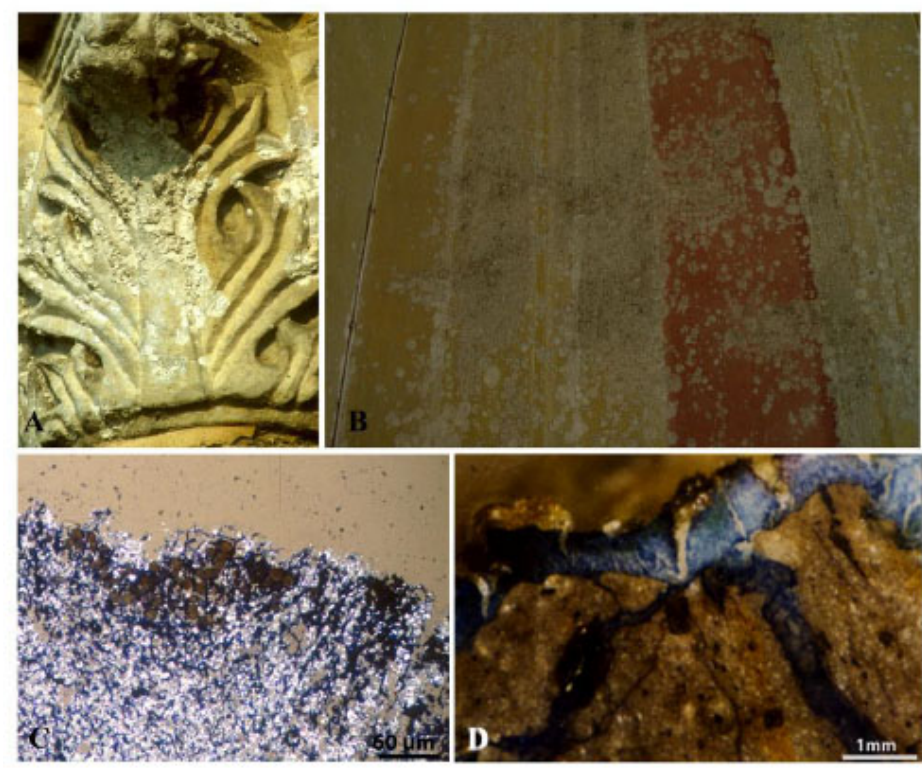

Fig. (5). Dirina massiliensis growing on a marble capital of S. Fosca church (Torcello, Venice) (A) and on frescoes of Villa Rossi (Gattaiola, Tuscany) (B). (C) Thin section, cross polarized light, showing the large amount of calcium oxalate formed and deposited outside fungal hyphae (in blue). (D) Cross section showing the lichen thallus and large bundle of hyphae (in blue) penetrating into the substrate. 


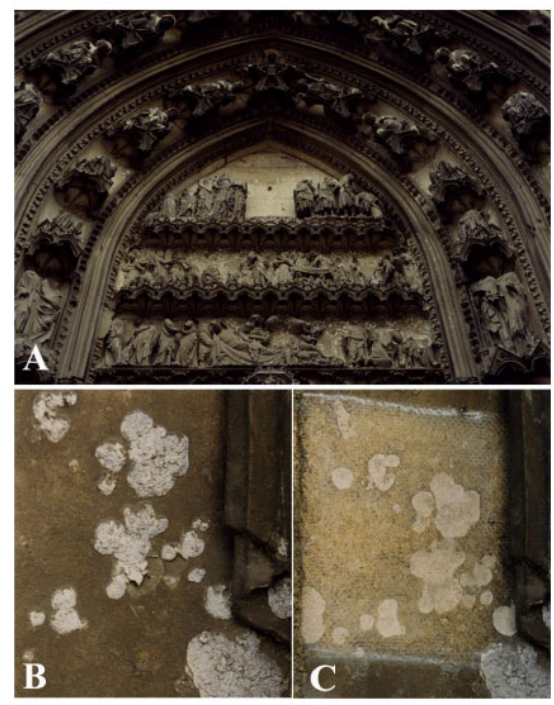

Fig. (6). Portal of Mantes cathedral (France) colonized by Dirina massiliensis (A). Particular of thalli growing on limestone (B) and the same area after the treatment and removal of lichens (C). Note the strong deterioration of substrate (erosion, loss of material) induced by lichens.

Inflated hyphae, also called oil hyphae for the high lipid content, are peculiar to endolithic lichens and represent a morphophysiological adaptation to a peculiar environment although their function is not properly understood. Moreover, the presence of many hyphal clews arranged in more or less sphaerical voids (c. 20-80 $\mu \mathrm{m}$ in diameter) produced by the dissolution of the substrate, at a certain distance from the surface, were recognized in three endolithic species, Petractis clausa, Encephalographa elisae, and Strigula endolithea, [88, 92, 93] (Fig. 7B, C). The function of these structures and as much they are widespread in endolithic lichens is unknown. Nevertheless, this should be taken into account in the evaluation of the effects of restoration treatments to kill endolithic lichens that could determine an increase in the water-holding capacity of the stone leaving empty cavities and ducts on and within the rock.

The production of calcium oxalates in endolithic lichens, unlike epilithic species, does not seem to be a peculiar characteristic; it was surely detected only in one species, Verrucaria rubrocincta [89]. The finding of calcium oxalate in some species by few authors [94 - 96] was not confirmed by others [88, 90, 97, 98]. Moreover, Verrucaria rubrocincta penetrates more than $0.5 \mathrm{~cm}$ and forms a surface layer of fine-grained calcite (micrite), with sparse hyphae, which accumulates on the surface; this micrite is absent on the unhabited rocks, witnessing a biomineralisation process [89].
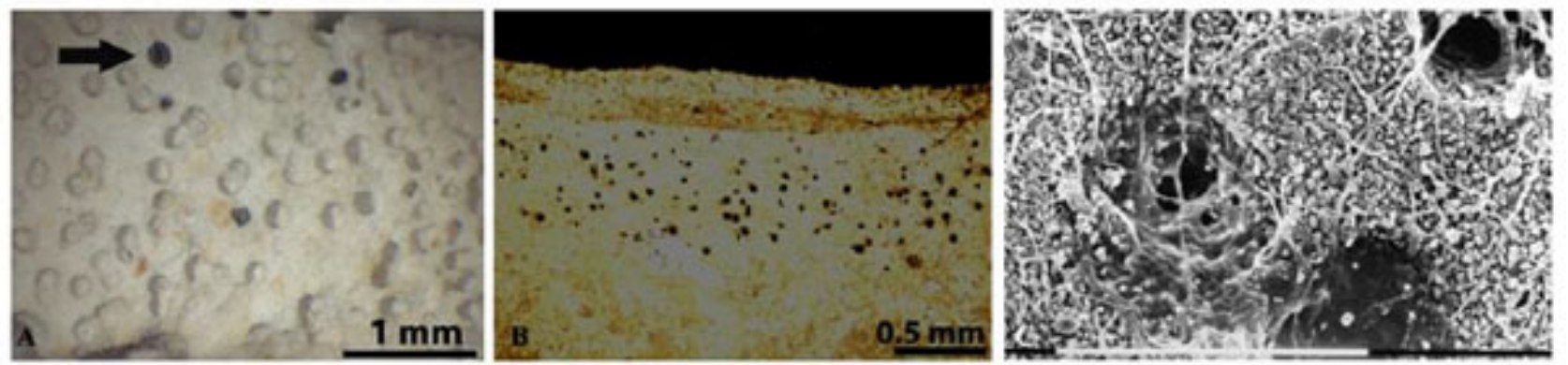

Fig. (7). Biopitting on a limestone surface after a biocidal treatment of an endolithic lichen (A), arrow: perithecium. Thin section of Petractis clausa on limestone showing the distribution pattern of voids created by the lichen (B). Interconnections of hyphae in and among the voids $(\mathbf{C})(\mathrm{bar}=0,1 \mathrm{~mm})$.

Mycobionts and photobiont of two endolithic lichens (Bagliettoa baldensis and B. marmorea) were isolated and inoculated on limestone and four marbles to investigate lichen-rock interactions under controlled conditions and the results were compared with the analyses of lichen colonization in situ [99]. After one year of incubation of mycobionts, different penetration depth and patterns were observed according to the different lithotypes, strongly depending on their 
petrographic features. Hyphal penetration in the rocks in situ was, as expected, stronger. Algae did not penetrate the rock specimens in vitro after a year, supporting the hypothesis that their occurrence within the rock is not due to an active penetration.

Endolithic lichens actively dissolve carbonates by means of an unknown mechanism, purportedly related to the secretion of chelating substances, or the release of respiratory carbon dioxide. The production of active forms of carbonic anhydrase, an enzyme which catalyses the reversible hydration of $\mathrm{CO}_{2}$, was demonstrated by immunofluorescence and histochemical localization and in vivo activity tests in endolithic lichens immersed in the substrate or free of it [100]. The enzyme accelerates the hydration of respiratory $\mathrm{CO}_{2}$ and consequently the dissolution of carbonate rocks. The involvement of oxalic acid in the dissolution of stone was excluded since the studied species do not produce calcium oxalate. Moreover, as previously reported for MCF, mycobionts of three endolithic lichens (Bagliettoa baldensis, B.marmorea and Acrocordia conoidea) actively penetrate and produce siderophore-like compounds in culture suggesting their possible involvement in the deterioration of both silicate and carbonate rocks [73].

\section{LICHENS: BIOPROTECTIVE OR BIODETERIORATIVE EFFECT?}

In spite of evident deterioration induced by lichens on stone monuments, all the other causes of weathering should be considered and evaluated very carefully. In some cases, lichens may exert a certain protection against other abiotic degradation factors even though they have deteriorative effects. Starting from nineties it was hypothesized that lichens could have a function of bioprotection towards stone monuments acting in an active or passive way. Lichens could have a protective role on porous stone reducing the intensity of water exchange and the action of other weathering agents such as wind, marine aerosols and pollution [76, 101, 102], and could also have a protective effect against sand disaggregation [103]. More widespread exfoliation, salt efflorescence, flaking, powdering and honeycombing of noncolonized surfaces would support this hypothesis. In the last decade, many authors sustained and investigated possible bioprotective effects exerted by both epilithic and endolithic lichens. Fiol et al. [104, 105] observed by in situ and laboratory experiments that the loss of lithic particles from a limestone surface was substantially reduced by lichen cover. Mottershead and Lucas [106] through in field observations and measures on the development of two epilithic lichens, Aspicilia calcarea and Diploschistes diacapsis, on a soluble rock (gypsum) stated their bioprotective action. The thalli act as a protective umbrella reducing the erosion of the substrate by the solvent effect of rain. Carter and Viles [107] demonstrated, with field and laboratory experiments, that Verrucaria nigrescens retains moisture in the thalli and reduces thermal stress in the surface of limestone. Chiari and Cossio [108] studied a sandstone, made main of pure quartz, covered by lichens. In the outer stone surfaces, colonized by epilithic lichens, weddellite - representing a typical byproduct of lichens and minerals from dust deposition were present, and no evidence of etching was observed. Moreover, the porosity of the core sandstone was the same of that measured in the outer part where hyphae filled the preexisting pores.

A conceptual model of bioprotection limestone by epilithic lichens was proposed by Carter and Viles [109]: lichens act as an umbrella protecting the substrate from rainfall and atmospheric deposition. Lichens can absorb/reflect solar radiation protecting the stone from temperature variations and thermal stress, depending on the colour of the thalli (dark thalli, e.g.Verrucaria nigrescens, absorb heat causing an increase of temperature fluctuations and thermal gradient in the rock surface) [110], also as a barrier protecting stone from water penetration, and reducing or neutralizing the negative action of wind, rain, pollutants and marine aerosols. A protective function is also attributed to a "patina and crust formation" after the death of lichens, mainly composed of oxalate remains with entrapped organic and mineral matter. The positive effect of the presence of hard, almost insoluble calcium oxalate patina at the lichen-rock interface is also stressed by McIlroy de la Rosa et al. [111]. Obviously the presence of hard, almost insoluble encrustations on stone surfaces may reduce the action of other weathering agents but the name 'patina' attributed to deposition or layers of oxalates resulting from lichens can lead to misunderstanding. As previously reported oxalate location on, within thalli and/or substrate varies a lot among species and lichen death generally entails the detachment of thalli and their content from the substrate without leaving an "hard, insoluble patina", except in some rare cases.

The lichen covered tuff of Cappadocian monuments showed a higher vapour diffusion resistance and slower penetration of water if compared with no-colonized one [112]. This moisture-controlling function of lichens was confirmed in a study carried out on the microflora colonizing the stone of Angkor Wat and other Cambodian temples $[30,113]$. The biodeterioration effects on minerals were demonstrated, nevertheless, the measurements of the capillary water uptake showed that lichens protect stone from rapid water uptake whereas cyanobacterial biofilm increases it. 
According to the authors "lichen patina regulated the humidity, thermal transmission and water vapor diffusion, reducing thermohygric stresses to the stone at Angkor Wat". Concha-Lozano et al. [114], comparing samples from well preserved and deteriorated limestone monuments in Nîmes and from quarries, found that the thick network of endolithic hyphae can act as a barrier increasing waterproofing of the stone and slowing down the sulphate diffusion into the stone. These results are very promising, nevertheless a standardization of water absorption measurements in situ should be necessary as environmental humidity, and consequently water content of lichens, could entail noteworthy variation in the results. The knowledge of the species on which measures are carried out is another very important factor. According to Hoppert et al. [62] homogeneous carbonate rocks, due to the absence of fissures, that are preferentially colonized by euendolithic organisms which actively bore cavities and channels in the substrate whereas siliceous, crystalline or sedimentary rocks are preferentially colonized by chasmoendolithis and cryptoendolithis which build up a network with the porous rocks temporarily stabilizing the surfaces and reducing weathering.

As regards endolithic lichens, colonizing most of the carbonatic rock surfaces, there is not a common statement about their protecting or deteriorating role. According to Carter and Viles [109] endolithic lichens are rarely likely to act bioprotectively. The exposition of lichen covered limestone to artificial rainfall demonstrated that Verrucaria nigrescens (epilithic), although causing certain deterioration, protects the stone surface from the action of water and other subaerial processes. $V$. baldensis (endolithic) creates a secondary porosity favouring the physic-chemical action of runoff and wind leading to surface lowering. The same species are considered bioprotectant during the lifespan of the lichen, but on long-term surface lowering of limestone previously colonized is likely to occur more rapidly than uncolonized surfaces [91]. Cucchi et al. [115] studied the effects of twenty endolithic lichens on limestone measuring in situ the rate of dissolution on colonized and uncolonized surfaces using a micro erosion meter (MEM) and a traversing erosion meter (TMEM). Preliminary results, after the first years of measurements, suggest a bioprotective action of endolithic lichens because no colonized surfaces show a greater rate of rock surface lowering.

Finally biodeterioration and bioprotection are not mutually exclusive and can occur simultaneously in a species or community. The experiments were generally carried out on one or few species and it is noteworthy that a species may act positively in a certain environment but adversely in another. Verrucaria nigrescens may act protectively in a wet temperate environment but in a dry hot environment the biodeteriorative effect may continue amplifying temperature fluctuations of the substrate [109].

From the examination of the literature on stone deterioration it is noticeable that the effect of a certain number of species on some lithotypes was deeply investigated showing differences and peculiarities in the decay induced by different species and even by the same species on different lithotypes. This is why it is often difficult to give an overall evaluation of lichen contribution to the deterioration of stone monuments showing abundant and manifold lichen colonization, as usually it is if environmental conditions are favourable to growth. An index of Lichen Potential Biodeteriogenic Activity (LPBA) was proposed to quantify lichen impact on stonework taking in account of cover, reproductive potency, depth of hyphal penetration, physical and chemical action, hyphal spread and bioprotection [116]. The application of the index to some case studies highlights its effectiveness for a more thorough evaluation of biodeterioration induced by lichens on different stoneworks with respect to cover only. Moreover, the authors suggest a statistical validation of the index carried out by an international research network, based on the examination of more case-studies on different lithotypes and various climatic regions.

It is well known that lichen colonization on outdoors monuments depends on many different factors: the environment, the orientation, the type of substrate, and the availability of nitrogen compound. A correct identification of lichen species is a fundamental preliminary step of whatever study, moreover the ecological study of lichen communities growing on monuments permits to investigate the most important factors favoring their growth and spreading, therefore it is very useful to evaluate if preventive measures can direct methods to eliminate them.

Moreover, it would be important monitoring the population or community dynamics on stone monuments, nevertheless few studies on this topic have been done. The dynamics of colonization of lithobiontic organisms were studied along a linear transect in a glacial recession area with known age of exposure: the first colonizers were fungi, followed by green algae and cyanobacteria and, finally, by endolithic lichens [62]; furthermore in all stages of biofilm development bacteria surrounded by extracellular polymeric substances (EPS) were present.

Only some papers focused on recolonization after restoration. Calcareous statues and marble sculptures located in a garden environment respectively in North Italy and Portugal were monitored. Species richness and composition of lichen communities on a calcareous statue before restoration and after 8 and 12 years were compared [117]. The 
percentage of colonized areas and the total number of species were higher before restoration (c. $90 \%, 25$ species) with respect to the second (c. $60 \%, 17$ species) and the third surveys (c. 70\%, 20 species). The comparison of lichen recolonization on statues of three Venetian villas showed that the use of hydrorepellent products failed to new lichen growth in the long term and, depending on the product used, first signs of biological colonization appeared after few weeks or months. In addition, a different hydrorepellent products application could give rise to unsightly streaking on stone surface due to preferential water paths and their subsequent biocolonization [118]. This pattern may be enhanced by the complex geometry of the statues. Nevertheless, the recolonization can be related to local environmental conditions in addition to the products and/or methodologies used during restoration [21, 119]. The development of a regular and long-term maintenance program together with the modification of environmental conditions, whenever possible, are the best choice for the preservation of stone monuments [22].

\section{CONCLUSION}

In spite of a lot of studies showing the deterioration of stone and minerals induced by fungi and lichens, many aspects concerning the mechanisms of biodeterioration achieved by MCF and endolithic lichens require further in-depth analyses. Important and promising results were obtained in the last years thanks to the progress in the cultivation of MCF and aposymbionts of endolithic lichens. A lot remains to be understood about the degree of diffusion among different species and the function of some peculiar characters, such as oil-hyphae and hyphal clews.

The bioprotective effects of epilithic and endolithic lichens were sustained and demonstrated by some experimental studies. Nevertheless, usually it is impossible to establish if a species, and even more a lichen community, possess a biodeteriorative or bioprotective effect, as it is also influenced by stone and environmental characteristics.

Likewise the population or community dynamics on stone monuments, before and after restoration, need more investigations and could give an important contribution to the conservation science in Cultural Heritage.

\section{CONFLICT OF INTEREST}

The authors confirm that this article content has no conflict of interest.

\section{ACKNOWLEDGEMENTS}

Declared none.

\section{REFERENCES}

[1] Warscheid, T.; Braams, J. Biodeterioration of stone: a review. Int. Biodeterior. Biodegradation, 2000, 46(4), $343-368$. [http://dx.doi.org/10.1016/S0964-8305(00)00109-8]

[2] Scheerer, S.; Ortega-Morales, O.; Gaylarde, C. Microbial deterioration of stone monuments - an updated overview. Adv. Appl. Microbiol., 2009, 66, 97-139.

[http://dx.doi.org/10.1016/S0065-2164(08)00805-8]

[3] Caneva, G.; Nugari, M.P.; Salvadori, O. Plant Biology for Cultural Heritage: Biodeterioration and Conservation; The Getty Conservation Institute: Los Angeles, 2008.

[4] Krumbein, W.E. Zur Frage der Gesteinsverwitterung (Über geo-chemische undmikrobiologische Bereiche der exogenen Dynamik). PhD Thesis, Würzburg, Germany, 1966.

[5] Krumbein, W.E.; Urzì, C. Biologically Induced Decay Phenomena of Antique Marbles-Some General Considerations.. In: The conservation of monuments in the Mediterranean basin. Proceeding $2^{\text {nd }}$ Int Symp; Decrouez, D; Chamy, J; Zezza, F, Eds.; Musee d'Art et d'Histoire Naturelle: Geneve, 1993; pp. 219-35.

[6] Gorbushina, A.A.; Krumbein, W.E.; Hamman, C.H. Role of fungi in the color change and biodeterioration of antique marbles. Geomicrobiol. J., 1995, 11, 205-211. [http://dx.doi.org/10.1080/01490459309377952]

[7] Piervittori, R.; Salvadori, O.; Laccisaglia, A. Literature on lichens and biodete-rioration of stonework. I. Lichenologist, 1994, 26 , 171-192. [http://dx.doi.org/10.1017/S0024282994000241]

[8] Piervittori, R.; Salvadori, O.; Laccisaglia, A. Literature on lichens and biodete-rioration of stonework. II. Lichenologist, 1996, 28, 471-483.

[9] Piervittori, R.; Salvadori, O.; Isocrono, D. Literature on lichens and biodeterio-ration of stonework. III. Lichenologist, 1998, $30,263-277$. [http://dx.doi.org/10.1006/lich.1998.0131]

[10] Piervittori, R.; Salvadori, O.; Isocrono, D. Literature on lichens and biodeterioration of stonework. IV. Lichenologist, 2004, 36, 145-157. [http://dx.doi.org/10.1017/S0024282904014136] 
[11] Piervittori, R.; Salvadori, O.; Seaward, M.R. Lichens and monuments: an analytical bibliography. In: Biodeterioration of stone surfaces. Lichens and biofilms as weathering agents of rocks and cultural heritage; St. Clair, L.L.; Seaward, M.R., Eds.; Kluwer Academic Publishers, 2004; pp. 241-282.

[12] Wilson, M.J. Interactions between lichens and rocks; a review. Cryptogam. Bot., 1995, 5, 299-305.

[13] Adamo, P.; Violante, P. Weathering of rocks and neogenesis of minerals associated with lichen activity. Appl. Clay Sci., 2000, 16, 229-256. [http://dx.doi.org/10.1016/S0169-1317(99)00056-3]

[14] Chen, J.; Blume, H.P.; Bejer, L. Weathering of rocks induced by lichen colonization - a review. Catena, 2000, 39, 121-146. [http://dx.doi.org/10.1016/S0341-8162(99)00085-5]

[15] St.Clair, L.L.; Seaward, M.R. Biodeterioration of Stone Surfaces. Lichens and Biofilms as Weathering Agents of Rocks and Cultural heritage; Kluwer Academic Publishers, 2004.

[16] Piervittori, R.; Favero-Longo, S.E.; Gazzano, C. Lichens and biodeterioration of stonework: a review. Chem Today, 2009, $27(6)$, 8-11.

[17] Golubic, S.; Friedmann, I.; Schneider, J. The lithobiontic ecological niche, with special reference to microorganisms. J. Sediment. Petrol., 1981, 51(2), 475-478.

[18] Warscheid, T. The evaluation of biodeterioration processes on cultural objects and approaches for their effective control. In: Art, biology and conservation: biodeterioration of works of art; Koestler, R.J.; Koestler, V.H.; Charola, A.E.; Nieto-Fernandez, F.E., Eds.; The Metropolitan Museum of Art: New York, 2003; pp. 14-27.

[19] Guillitte, O. Bioreceptivity: a new concept for building ecological studies. Sci. Total Environ., 1995, 167, 215-220. [http://dx.doi.org/10.1016/0048-9697(95)04582-L]

[20] Silva, A.; Prieto, B.; Rivas, T.; Sanchez-Biezma, M.J.; Paz, G.; Carballal, R. Rapid biological colonization of a granitic building by lichens. Int. Biodeterior. Biodegradation, 1997, 40, 263-267. [http://dx.doi.org/10.1016/S0964-8305(97)00051-6]

[21] Delgado, R.J.; Vale, A.M.; Charola, A.E. Recolonization of marble sculptures in a garden environments. In: Biocolonization of stone: control and preventive methods; Charola, A.E.; McNamara, C.; Koestler, R.J., Eds.; Smithsonian Institution Scholarly Press: Washington, DC, 2011; pp. 71-85.

[22] Salvadori, O.; Charola, A.E. Methods to prevent biocolonization and recolonization: an overview of current research for architectural and archaeological heritage. In: Biocolonization of Stone: Control and Preventive Methods; Charola, A.E.; McNamara, C.; Koestler, R.J., Eds.; Smithsonian Institution Scholarly Press: Washington, DC, 2011; pp. 37-50.

[23] Sterflinger, K. Fungi as geological agents. Geomicrobiol. J., 2000, 17, 97-24. [http://dx.doi.org/10.1080/01490450050023791]

[24] De Leo, F.; UrzA , C. Fungal colonization on treated and untreated stone surfaces. In: Molecular Biology and Cultural Heritage Swets \& Zeitlinger; Saiz-Jimenez, C., Ed.; Lisse, 2003; pp. 213-217.

[25] Gorbushina, A. Life on the rocks. Environ. Microbiol., 2007, 9(7), 1613-1631. [http://dx.doi.org/10.1111/j.1462-2920.2007.01301.x]

[26] Cutler, N.; Viles, H. Eukaryotic microorganisms and stone biodeterioration. Geomicrobiol. J., 2010, $27,630-646$. [http://dx.doi.org/10.1080/01490451003702933]

[27] Hirsch, P.; Eckhardt, F.E.; Palmer, R.J. Fungi active in weathering of rock and stone monuments. Can. J. Bot., 1995, 73, S1384-S1390. [http://dx.doi.org/10.1139/b95-401]

[28] Braams, J. Ecological Studies on the Fungal Microflora Inhabiting Histotical Sanstone Monuments. Ph.D. Thesis, Oldenburg, $1992 ., 104$.

[29] Kumar, R.; Kumar, A.V. Biodeterioration of Stone in Tropical Environments. An overview; The Getty Conservation Institute, 1999.

[30] Warscheid, T.; Leisen, H. Microbiological Studies on Stone Deterioration and Development of Conservation Measures at Angkor Wat.. In: Proceedings from the MCI Workshop Series; Charola, AE; McNamara, C; Koestler, RJ, Eds.; Smithsonian Institution Scholarly Press: Washington D.C., 2011; pp. 1-18.

[31] Karbowska-Berent, J. Microbiodeterioration of mural paintings: a review. In: Art, Biology and Conservation: Biodeterioration of Works of Art; Koestler, R.J.; Koestler, V.H.; Charola, A.E.; Nieto-Fernandez, F.E., Eds.; The Metropolitan Museum of Art: New York, 2003; pp. 266-301.

[32] Garg, K.L.; Jain, K.K.; Mishra, A.K. Role of fungi in the deterioration of wall paintings. Sci. Total Environ., 1995, 167, $255-271$. [http://dx.doi.org/10.1016/0048-9697(95)04587-Q]

[33] Zucconi, L.; Gagliardi, M.; Isola, D. Biodeterioration agents dwelling in or on the wall paintings of the Holy Saviour's cave (Vallerano, Italy). Int. Biodeterior. Biodegradation, 2012, 70, 40-46.

[http://dx.doi.org/10.1016/j.ibiod.2011.11.018]

[34] Sterflinger, K.; de Hoog, G.S.; Haase, G. Phylogeny and ecology of meristematic Ascomycetes. Stud. Mycol., 1999, 43, 5-22.

[35] Sterflinger, K.; Tesei, D.; Zakharova, K. Fungi in hot and cold deserts with particular reference to microcolonial fungi. Fungal Ecol., 2012, 5, 453-462.

[http://dx.doi.org/10.1016/j.funeco.2011.12.007] 
[36] Wollenzien, U.; de Hoog, G.S.; Krumbein, W.E.; UrzA, C. On the isolation of microcolonial fungi occurring on and in marble and other calcareous rocks. Sci. Total Environ., 1995, 167, 287-294. [http://dx.doi.org/10.1016/0048-9697(95)04589-S]

[37] Ruibal, C.; Platas, G.; Bills, G.F. Isolation and characterization of melanised fungi from limestone formations in Mallorca. Mycol. Prog., 2005, 4(1), 23-28. [http://dx.doi.org/10.1007/s11557-006-0107-7]

[38] Onofri, S.; Zucconi, L.; Isola, D.; Selbmann, L. Rock-inhabiting fungi and their role in the deterioration of stone monuments in the Mediterranean area. Plant Biosyst., 2014, 148(2), 384-391. [http://dx.doi.org/10.1080/11263504.2013.877533]

[39] Burford, Ep.; Kierans, M.; Gadd, M. Geomycology: fungi in mineral substrata. Mycologist, 2003, $17,98-07$.

[40] Gadd, G.M. Geomycology: biogeochemical transformations of rocks, minerals, metals and radionuclides by fungi, bioweathering and bioremediation. Mycol. Res., 2007, 111, 3-49. [http://dx.doi.org/10.1016/j.mycres.2006.12.001]

[41] De la Torre, M.A.; Gomez Alarcon, G.; Vizcaino, C.; Garcia, M.T. Biochemical mechanisms of stone alteration carried out by filamentous fungi living in monuments. Biogeochemistry, 1993, 19, 129-147. [http://dx.doi.org/10.1007/BF00000875]

[42] Fomina, M.; Burford, E.P.; Hillier, S.; Kierans, M.; Gadd, G.M. Rock-building fungi. Geomicrobiol. J., 2010, $27,624-629$. [http://dx.doi.org/10.1080/01490451003702974]

[43] Callot, G.; Maurett, M.; Pottier, I.; Dubois, A. Biogenic etching of microfractures in amorphous and cristalline silicates. Nature, 1987, 328, 147-149. [http://dx.doi.org/10.1038/328147a0]

[44] Mohammadi, P. Inhabiting and deteriorating fungi from carbonate monuments of persepolis - isolation, characterization, and inhibitory treatment. PhD Thesis, Carl von Ossietzky University: Oldenburg, 2007.

[45] Burford, E.P.; Fomina, M.; Gadd, G.M. Fungal involvement in bioweathering and biotransformation of rocks and minerals. Mineral. Mag., 2003, 67, 1127-1155. [http://dx.doi.org/10.1180/0026461036760154]

[46] Resende, M.A.; Rezende, G.C.; Viana, E.V.; Becker, T.W.; Warscheid, T. Acid production by fungi isolated from historic monuments in the Brazilian state of Minas Gerais. In: Biodegradation \& Biodeterioration in Latin America; Gaylarde, C.C.; de SaA', E.L.; Gaylarde, P.M., Eds.; Mircen/UNEP/UNESCO/ICRO-FEPAGRO/UFRGS: Porto Alegre, 1996; pp. 65-67.

[47] GA3mez-Cornelio, S.; Mendoza-Vega, J.; Gaylarde, C.C. Succession of fungi colonizing porous and compact limestone exposed to subtropical environments. Fungal Biol., 2012, 116(10), 1064-1072.

[http://dx.doi.org/10.1016/j.funbio.2012.07.010]

[48] Sterflinger, K.; Krumbein, W.E. Dematiaceous fungi as a major agent for biopitting on Mediterranean marbles and limestones. Geomicrobiol. J., 1997, 14, 219-230. [http://dx.doi.org/10.1080/01490459709378045]

[49] Saiz-Jimenez, C. Biodeterioration vs. biodegradation: the role of microorganisms in the removal of pollutants deposited onto historic buildings. Int. Biodeterior. Biodegradation, 1997, 40, 225-232. [http://dx.doi.org/10.1016/S0964-8305(97)00035-8]

[50] Viles, H.A.; Gorbushina, A.A. Soiling and microbial colonisation on urban roadside limestone: a three year study in Oxford, England. Build. Environ., 2003, 38, 1217-1224. [http://dx.doi.org/10.1016/S0360-1323(03)00078-7]

[51] Moroni, B.; Pitzurra, L. Biodegradation of atmospheric pollutants by fungi: a crucial point in the corrosion of carbonate building stone. Int Biodeterior. Biodegradation, 2008, 62, 391-396. [http://dx.doi.org/10.1016/j.ibiod.2008.03.011]

[52] Gorbushina, A.A.; Whitehead, K.; Dornieden, T.; Niesse, A.; Schulte, A.; Hedges, J.I. Black fungal colonies as unit of survival: hyphal mycosporines synthesized by rock dwelling microcolonial fungi. Can. J. Bot., 2003, 81, 131-138. [http://dx.doi.org/10.1139/b03-011]

[53] Salvadori, O. Characterization of endolithic communities of stone monuments and natural outcrops. In: Of Microbes and Art the Role of Microbial Communities in the Degradation and Protection of Cultural Heritage; Ciferri, O.; Tiano, P.; Mastromei, G., Eds.; Kluwer Academic/Plenum Publishers: New York, 2000; pp. 89-01.

[54] UrzA , C.; De, L.F.; De, H.S.; Sterflinger, K. Recent advances in the molecular biology and ecophysiology of meristematic fungi. In: Of Microbes and Art the Role of Microbial Communities in the Degradation and Protection of Cultural Heritage; Ciferri, O.; Tiano, P.; Mastromei, G., Eds.; Kluwer Academic/Plenum Publishers: New York, 2000; pp. 3-19.

[55] De, L.F.; Criseo, G.; UrzA, C. Impact of the Surrounding Vegetation and Soil on the Colonization of Marble Statues by Dematiaceous Fungi. In: Proceedings of the $8^{\text {th }}$ International Congress on Deterioration and Conservation of Stone; Berlin, 1996; pp. 625-30.

[56] Urzì, C.; Realini, M. Colour changes of Noto's calcareous sandstone as related to its colonization by microorganisms. Int. Biodeterior. Biodegradation, 1998, 42, 45-54. 
[http://dx.doi.org/10.1016/S0964-8305(98)00045-6]

[57] Chertov, O.; Gorbushina, A.; Deventer, B. A model for microcolonial fungi growth on rock surfaces. Ecol. Modell., 2004, 177(3-4), 415-426. [http://dx.doi.org/10.1016/j.ecolmodel.2004.02.011]

[58] Muggia, L.; Gueidan, C.; Knudsen, K.; Perlmutter, G.; Grube, M. The lichen connection of black fungi. Mycopathologia, 2013, 175(5-6), 523-535. [http://dx.doi.org/10.1007/s11046-012-9598-8]

[59] Sterflinger, K. Fungi: Their role in deterioration of cultural heritage. Fungal Biol. Rev., 2010, 24, 47-55. [http://dx.doi.org/10.1016/j.fbr.2010.03.003]

[60] Urzi, C.; De Leo, F.; Salamone, P.; Criseo, G. Impact of Airborne Fungi on Marble Objects Exposed at Messina Euromarble Site. In: Proceedings of the $9^{\text {th }}$ Eurocare Euromarble workshop EU 496; Munich, 1998; pp. 39-55.

[61] Sterflinger, K. Patination of Marble at "Euromarble” Exposure Sites Iron Stain vs. Biopigments. In: Proceedings of the $9^{\text {th }}$ Eurocare Euromarble workshop EU 496; Forschungsbericht 17/99 Bayerisches Landesamt für Denkmalpflege : Munich, 1998; pp. 83-91.

[62] Hoppert, M.; Flies, C.; Pohl, W.; GA1/4nzl, B.; Schneider, J. Colonization strategies of lithobiontic microorganisms on carbonate rocks. Environ Geol., 2004, 46, 421-428. [http://dx.doi.org/10.1007/s00254-004-1043-y]

[63] Koestler, R.J. Polymers and resins as food for microbes. In: Microbes and Art the Role of Microbial Communities in the Degradation and Protection of Cultural Heritage; Ciferri, O.; Tiano, P.; Mastromei, G., Eds.; Kluwer Academic/Plenum Publishers: New York, 2000; pp. 153-167. [http://dx.doi.org/10.1007/978-1-4615-4239-1_11]

[64] Pinna, D.; Salvadori, O. Biological Growth on Italian Monuments Restored with Organic or Carbonatic Compounds.. In: Proceedings of the International Conference on Microbiology and Conservation ICMC' 99; Florence, Italy, 1999; pp. 149-54.

[65] Camara, B.; De los Rios, A.; GarcA-a-del-Cura, M.A.; Galvan, V.; Ascaso, C. Dolostone bioreceptivity to fungal colonization. Materiales de Costruccia3n, 2008, 58, 113-124.

[66] De los RA-os, A.; Cámara, B.; GarcA-a del Cura, M.A.; Rico, V.J.; Galván, V.; Ascaso, C. Deteriorating effects of lichen and microbial colonization of carbonate building rocks in the Romanesque churches of Segovia (Spain). Sci. Total Environ., 2009, 407, 1123-1134. [http://dx.doi.org/10.1016/j.scitotenv.2008.09.042]

[67] Caneva, G.; Nugari, M.P.; Ricci, S.; Salvadori, O. Pitting of Marble Roman Monuments and the Related Microflora. In: Proceedings International Congress on Deterioration and Conservation of Stone; Lisbon, LNEC, 1995; pp. 521-30.

[68] Lombardozzi, V.; CastrignanÓ, T.; D' Antonio, M.; Casanova Municchia, A.; Caneva, G. An interactive database for an ecological analysis of stone pitting. Int. Biodeterior. Biodegradation, 2012, 73, 8-15.

[http://dx.doi.org/10.1016/j.ibiod.2012.04.016]

[69] Diakumaku, E.; Gorbushina, A.A.; Krumbein, W.E.; Panina, L.; Soukharjevski, S. Black fungi in marble And limestone - an aesthetical, chemical and physical problem for the conservation of monuments. Sci. Total Environ., 1995, 167, 295-04. [http://dx.doi.org/10.1016/0048-9697(95)04590-W]

[70] Sterflinger, K.; Krumbein, W.E.; Rüllkötter, J. Patination of marble, sandstone and granite by microbial communities. Z. Dtsch. Geol. Ges., 1999, 150, 299-11.

[71] Gorbushina, A.A.; Krumbein, W.E.; Hamman, C.H.; Panina, L.; Soukharijevski, S.; Wollenzien, U. Role of black fungi in color change and biodeterioration of antique marbles. Geomicrobiol. J., 1995, 11, 205-221. [http://dx.doi.org/10.1080/01490459309377952]

[72] Dornieden, T.; Gorbushina, A.A. New Methods to Study the Detrimental Effect of Poikilotroph Microcolonial Micromycetes (PMM) on Building Materials. In: Proceedings of the $9^{\text {th }}$ International Congress on Deterioration and Conservation of Stone; Fassina, V, Ed.; Venice, Italy, 2000; pp. 461-8. [http://dx.doi.org/10.1016/B978-044450517-0/50129-X]

[73] Favero-Longo, S.E.; Gazzano, C.; Girlanda, M. Physical and chemical deterioration of silicate and carbonate rocks by meristematic microcolonial fungi and endolithic lichens (Chaetothyriomycetidae). Geomicrobiol. J., 2011, 28, 732-744. [http://dx.doi.org/10.1080/01490451.2010.517696]

[74] Salvadori, O.; Lazzarini, L. Lichen deterioration of stones of Aquileian monuments (Italy). Botanika Chronika, 1991, 10, 961-968.

[75] Salvadori, O.; Tretiach, M. Thallus-substratum relationship of silicicolous lichens occurring on carbonatic rocks in the Mediterranean regions. In: Progress and Problems in Lichenology at the Turn of Millennium - IAL 4 Bibliotheca Lichenologica; Llimona, X.; Lumbsch, H.T.; Ott, S., Eds.; , 2002; vol. 82, pp. 57-4.

[76] Wendler, E.; Prasartset, C. Lichen Growth on Old Khmer-Style Sandstone Monuments in Thailand: Damage Factors or Shelter?. In: Preprints of the $12^{\text {th }}$ Triennal Meeting; ICOM Committee for Conservation: London, Lyon, 1999; vol. 2, pp. vol. 2750-54.

[77] Prieto, B.; Rivas, T.; Silva, B. Colonization by lichens of granite churches in Galicia (northwest Spain). Sci. Total Environ., 1995, 167, 343-351. [http://dx.doi.org/10.1016/0048-9697(95)04594-Q]

[78] Ascaso, C.; Wierzchos, J.; Castello, R. Study of the biogenic weathering of calcareous litharenite stones caused by lichen and endolithic 
microorgan-isms. Int. Biodeterior. Biodegradation, 1998, 42, 29-8.

[http://dx.doi.org/10.1016/S0964-8305(98)00043-2]

[79] Gorgoni, C.; Lazzarini, L.; Salvadori, O. Minero-Geochemical Transformations Induced by Lichens in the Biocalcarenite of the Selinuntine Monuments.. In: Proceedings International Congress on Deterioration and Conservation of Stone; , 1992; pp. Lisbon, LNEC531-9.

[80] Favero-Longo, S.E.; Castelli, D.; Salvadori, O.; Belluso, E.; Piervittori, R. Pedogenetic action of the lichens Lecidea atrobrunnea, Rhizocarpon geographicum gr. and Sporastatia testudinea on serpentinized ultramafic rocks in an alpine environment. Int. Biodeterior. Biodegradation, 2005, 56, 17-7.

[http://dx.doi.org/10.1016/j.ibiod.2004.11.006]

[81] Salvadori, O.; Pinna, D.; Grillini, G.C. Lichen-Induced Deterioration on an Ignimbrite of the Vulsini Complex (Central Italy). In: Proceedings of the International Meeting Lavas and volcanic tuffs; Charola, AE; Koestler, RJ; Lombardi, G, Eds.; ICCROM 1994: Easter Island, Chile Roma, 1990; pp. 143-54.

[82] Bjelland, T.; Thorseth, I.H. Comparative studies of the lichen-rock interfaces of four lichens in Vingen, Western Norway. Chem. Geol., 2002, 192, 81-98. [http://dx.doi.org/10.1016/S0009-2541(02)00193-6]

[83] Ascaso, C. Contributions of in situ microscopy to the current understanding of stone biodeterioration. Int. Microbiol., 2005, 8(3), 181-188.

[84] Fry, E.J. The mechanical action of crustaceous lichens on substrata of shale, schist, limestone and obsidian. Ann. Bot. (Lond.), $1927,12,41$.

[85] Edwards, H.G.; Farwell, D.W.; Seaward, M.R. FT-Raman spectroscopy of Dirina massiliensis f. sorediata encrustations growing on diverse substrata. Lichenologist, 1997, 29, 83-90.

[86] Seaward, M.R. Major impacts made by lichens in biodeterioration processes. Int. Biodeterior. Biodegradation, 1997, 40, $269-273$. [http://dx.doi.org/10.1016/S0964-8305(97)00056-5]

[87] Nimis, P.L.; Tretiach, M. Studies on the Biodeterioration Potential of Lichens, with Particular Reference to Endolithic Forms. Interactive physical weathering and bioreceptivity study on building stones, monitored by Computerized X-ray Tomography (CT) as a potential research tool, Environment/Protection and Conservation of European Cultural Heritage. Research Report., 1995., 63-22.

[88] Pinna, D.; Salvadori, O.; Tretiach, M. An anatomical investigation of calcicolous endolithic lichens from the Trieste karst (NE Italy). Plant Biosyst., 1998, 132(3), 183-195. [http://dx.doi.org/10.1080/11263504.1998.10654203]

[89] Bungartz, F.; Garvie, L.A.; Nash, T.H., III Anatomy of the endolithic Sonoran Desert lichen Verrucaria rubrocincta Breuss: implications for biodeterioration and biomineralization. Lichenologist, 2004, 36, 55-73. [http://dx.doi.org/10.1017/S0024282904013854]

[90] Pinna, D.; Salvadori, O. Endolithic Lichens and Conservation: An Underestimate Question. In: Proceedings $9^{\text {th }}$ International Congress on Deterioration and Conservation of Stone; Elsevier: Lisbon, 2000; Vol. 1, pp. Vol. 1513-19. [http://dx.doi.org/10.1016/B978-044450517-0/50136-7]

[91] McIlroy de la Rosa, J.P.; Warke, P.A.; Smith, B.J. Microscale biopitting by the endolithic lichen Verrucaria baldensis and its proposed role in mesoscale solution basin development on limestone. Earth Surf. Process. Landf., 2011, 37, 374-384. [http://dx.doi.org/10.1002/esp.2244]

[92] Tretiach, M.; Modenesi, P. Critical notes on the lichen genus Encephalographa A. Massal. (?Hysteriaceae). Nova Hedwigia, 1999, 68, 527-544.

[93] Tretiach, M.; Rinino, S. Critical notes on the calcicolous endolithic lichen Strigula endolithea (Strigulaceace, Ascomycota). Nova Hedwigia, 2006, $83,451-458$.

[http://dx.doi.org/10.1127/0029-5035/2006/0083-0451]

[94] Gehrmann, C.K.; Krumbein, W.E. Interaction between Epilithic and Endolithic Lichens and Carbonate Rocks.. In: Proceedings of the ${ }^{\text {rd }}$ International Symposium, The Conservation of Monuments in the Mediterranean basin; Fassina, V; Ott, H; Zezza, F, Eds.; Venice, 1994; pp. 311-6.

[95] Gehrmann, C.K.; Krumbein, W.E. Biomineralization in epilithic and endolithic lichens.. In: Proceedings of the $3^{\text {rd }}$ IAL Symposium, Progress and Problems in Lichenology in the Nineties; Salzburg, 1996; p. 157.

[96] Gehrmann-Janssen, C.K. On the Biopitting Corrosion by Epilithic and Endolithic Lichens on Carbonate Rocks - Biophysical and Biochemical Weathering Aspects. PhD. Thesis, University of Oldenburg, 1995.

[97] Pomar, L.; Esteban, M.; Llimona, X.; Fontarnau, R. AccA-on de 1A quenes, algas y hongos en la telodiagA"nesis de las rocas carbonatadas de la zona litoral prelitoral catalana. Inst. Inv. Geol. Univ. Barcelonal., 1975, 30, 83-117.

[98] Favali, M.A.; Fossati, F.; Mioni, A.; Realini, M. Biodeterioramento da licheni crostosi dei calcari selciferi lombardi.. In: Proceedings of the $11^{\text {th }}$ Congress; Biscontin, G.; Driussi, G., Eds.; Scienza e Beni Culturali: Padova, Libreria Progetto, 1995; pp. $201-9$.

[99] Tretiach, M.; Favero-Longo, S.E.; Crisafulli, P. How do endolithic lichens dissolve carbonates? In: Biology of Lichens and Bryophytes: Lichenological Abstracts - Miscellaneous Publication NA of the American Bryological Society and the International Association for Lichenology; Nash, T.H., III; Seaward, M.R., Eds.; Tempe, AZ, 2008; p. 72.

[100] Favero-Longo, S.E.; Borghi, A.; Tretiach, M.; Piervittori, R. In vitro receptivity of carbonate rocks to endolithic lichen-forming aposymbionts. Mycol. Res., 2009, 113, 1216-1227. 
[http://dx.doi.org/10.1016/j.mycres.2009.08.006]

[101] Lallement, R.; Deruelle, S. Presence De Lichens Sur Les Monuments En Pierre: Nuisance Ou Protection?. In: Proceedings of the International Symposium on Alteration and protection of stone monuments; Paris, Unesco-Rilem, 1978; 2, pp. 2(4.6)1-6.

[102] Ariño, X.; Ortega-Calvo, J.J.; Gomez-Bolea, A.; Saiz-Jimenez, C. Lichen colonization of the Roman pavement at Baelo Claudia (Cadiz, Spain): biodeterioration vs. bioprotection. Sci. Total Environ., 1995, 67, 353-363. [http://dx.doi.org/10.1016/0048-9697(95)04595-R]

[103] Carballal, R.; Paz-BermA dez, G.; SA nchez-Biezma, M.J.; Prieto, B. Lichen colonization of coastal churches in Galicia: biodeterioration implications. Int. Biodeterior. Biodegradation, 2001, 47, 157-163.

[http://dx.doi.org/10.1016/S0964-8305(01)00044-0]

[104] Fiol, L.I.; FornA3s, J.J.; Gines, A. El rillenkarren: un tipus particular de biokarst? Primeres dades. Endins, 1992, 17-18, 43-49.

[105] Fiol, L.I.; FornA3s, J.J.; Gines, A. Effects of biokarstic processes on the development of solutional rillenkarren in limestone rocks. Earth Surf. Process. Landf., 1996, 21, 447-452. [http://dx.doi.org/10.1002/(SICI)1096-9837(199605)21:5<447::AID-ESP607>3.0.CO;2-X]

[106] Mottershead, D.; Lucas, D. The role of lichens in inhibiting erosion of a soluble rocks. Lichenologist, 2000, 32(6), 601-609. [http://dx.doi.org/10.1006/lich.2000.0300]

[107] Carter, N.E.; Viles, H.A. Experimental investigations into the interactions between moisture, rock surface temperatures and an epilithic lichen cover in the bioprotection of limestone. Build. Environ., 2003, 38, 1225-1235. [http://dx.doi.org/10.1016/S0360-1323(03)00079-9]

[108] Chiari, G.; Cossio, R. Lichens of Wyoming sandstone: do they cause damage? In: Biodeterioration of Stone Surfaces. Lichens and Biofilms as Weathering Agents of Rocks and Cultural Heritage; St. Clair, L.L.; Seaward, M.R., Eds.; Kluwer Academic Publishers: USA, 2004; pp. 99-114.

[http://dx.doi.org/10.1007/978-1-4020-2845-8_7]

[109] Carter, N.E.; Viles, H.A. Bioprotection explored: the story of a little known earth surface process. Geomorphol. J., 2005, 67, $273-281$. [http://dx.doi.org/10.1016/j.geomorph.2004.10.004]

[110] Carter, N.E.; Viles, H.A. Lichen hotspots: raised rock temperatures beneath Verrucaria nigrescens on limestone. Geomorphol. J., 2004, 62, $1-16$.

[http://dx.doi.org/10.1016/j.geomorph.2004.02.001]

[111] McIlroy de la Rosa, J.P.; Warke, P.A.; Smith, B.J. Lichen induced biomodification of calcareous surfaces: bioprotection vs. biodeterioration Prog. Phys. Geogr., 2013, 37, 325-351. [http://dx.doi.org/10.1177/0309133312467660]

[112] Garcia-VallA"s, M.; Topal, T.; Vendrell-Saz, M. Lichenic growth as a factor in the physical deterioration or protection of Cappadocian monuments. Environ. Geol., 2003, 43, 776-781.

[113] Bartoli, F.; Municchia, C.A.; Futagami, Y.; Kashiwadani, H.; Moon, K.H.; Caneva, G. Biological colonization patterns on the ruins of Angkor temples (Cambodia) in the biodeterioration vs. bioprotection debate. Int. Biodeterior. Biodegradation, 2014, 96, 157-165. [http://dx.doi.org/10.1016/j.ibiod.2014.09.015]

[114] Concha-Lozano, N.; Gaudon, P.; Pages, J.; de Billerbick, G.; Lafon, D.; Eterradossi, O. Protective effect of endolithic fungal hyphae on oolithic limestone buildings. J. Cult. Herit., 2012, 13(2), 120-127. [http://dx.doi.org/10.1016/j.culher.2011.07.006]

[115] Cucchi, F.; Furlani, S.; Burelli, G.; Zini, L.; Tretiach, M. Variazioni microtopografiche di superfici carbonatiche colonizzate da licheni endolitici (Carso Giuliano, Maiella). Atti e Memorie della Commissione Grotte ?oE. Boegan, 2009, 42, 67-84.

[116] Gazzano, C.; Favero-Longo, S.E.; Matteucci, E.; Roccardi, A.; Piervittori, R. Index of Lichen Potential Biodeteriogenic Activity (LPBA): A tentative tool to evaluate the lichen impact in stonework. Int. Biodeterior. Biodegradation, 2009, 63, 836-43.

[117] Nascimbene, J.; Salvadori, O.; Nimis, P.L. Monitoring lichen recolonization on a restored calcareous statue. Sci. Total Environ., 2009, 407, 2420-2426.

[http://dx.doi.org/10.1016/j.scitotenv.2008.12.037]

[118] Charola, A.E.; Delgado, R.J.; Vale, A.M. Disfiguring biocolonization patterns after the application of water repellents. IJR, 2008, 14, $365-372$.

[119] Nascimbene, J.; Salvadori, O. Lichen recolonization on restored calcareous statues of three venetian villas. Int. Biodeterior. Biodegradation, 2008, 62, 313-318.

[http://dx.doi.org/10.1016/j.ibiod.2007.11.005]

Received: January 15, 2015

Accepted: July 31, 2015

(C) Salvadori and Municchia; Licensee Bentham Open.

This is an open access article licensed under the terms of the Creative Commons Attribution-Non-Commercial 4.0 International Public License (CC BY-NC 4.0) (https://creativecommons.org/licenses/by-nc/4.0/legalcode), which permits unrestricted, non-commercial use, distribution and reproduction in any medium, provided the work is properly cited. 